\title{
Business Model and Islamic Boarding School Business Development Strategy (Case Study Islamic Boarding School Sido Giri Pasuruan, East Java)
}

\section{Irham Zaki, Imron Mawardi, Tika Widiastuti, Achsania Hendratmi, and Risanda A. Budiantoro}

Faculty of Economics and Business, Universitas Airlangga, Jalan Airlangga No. 4 - 6, Gubeng, Surabaya 60015, Indonesia

\section{Abstract}

Islamic Boarding School is Islamic school that most of students are boarders. In the last 20 years, when the Islamic economy developed in Indonesia, many islamic boarding school established financial institutions and businesses that comply to Islamic law. The existence of the business and financial institutions (business network) were expected

Corresponding Author:

Irham Zaki

Irham-z@feb.unair.ac.id

Received: 10 February 2019

Accepted: 14 March 2019

Published: 28 March 2019

Publishing services provided by Knowledge E

(c) Irham Zaki et al. This article is distributed under the terms of the Creative Commons

Attribution License, which permits unrestricted use and redistribution provided that the original author and source are credited.

Selection and Peer-review under the responsibility of the ICIEBP Conference Committee. to encourage the implementation of Islamic law on economics and business in society, and also able to carry out economic and business practices according to sharia. This study will examine the existence of business network model and what are the benefits of business network model for the While in the era of colonialism adjustment occurs through the transformation of values where the islamic boarding school acts as an Islamic institution or institutionalization of Islamic values that have a mission-oriented ideology-political or religious-political. Where the motivation is to seize independence and liberate the people from the shackles of penghisaban by the invaders (Arifin, 2013). For now the existence of islamic boarding school is more related to learning process and education. In other words, islamic boarding school is a religious education institution capable of issuing certificates recognized in the national education system in Indonesia. This can be regarded as a islamic boarding school negotiation of new values that develop in society as a result of the advancement of science, knowledge, and technology (Izfannah, 2012).sustainability of business unit. The renewal of this research illustrates the business model practiced by islamic boarding school cottages especially PP Sidogiri as a whole and formulates the right business development strategy for business unit PP Sidogiri in order to maximize the role and social function of the islamic boarding school business unit. This research uses case study method on mixed islamic boarding school especially on Sidogiri Islamic Boarding School. The results of research to find out the ideal strategy in the implementation of business network as the development of a business model strategy of Islamic boarding schools in order to develop Islamic boarding school's business.

Keywords: Business Model, Strategy, Islamic Boarding School

\section{G OPEN ACCESS}




\section{Introduction}

In its development islamic boarding school has significant influence in creating Islamic culture in Indonesia, both as an enlightenment agent for student (santri) and Muslims, as well as value and cultural transformation agent that can bring the message of solidarity and peace. In the historical context, islamic boarding school is useful for studying the religious sciences as a lingua franca or language of communication in the various port cities of the archipelago and the kingdoms along the coast of the Indian Ocean. While in the era of colonialism adjustment occurs through the transformation of values where the islaic boarding school acts as an Islamic institution or institutionalization of Islamic values that have a mission-oriented ideology-political or religious-political. Where the motivation is to seize independence and liberate the people from the shackles of penghisaban by the invaders (Arifin, 2013). For now the existence of islamic boarding school is more related to learning process and education. In other words, islamic boarding school is a religious education institution capable of issuing certificates recognized in the national education system in Indonesia. This can be regarded as a islamic boarding school negotiation of new values that develop in society as a result of the advancement of science, knowledge, and technology (Izfannah, 2012).

So as an educational institution, islamic boarding school is expected to be independent in its operation. Therefore, islamic boarding school seeks to earn a halal income for the continuity of the teaching and learning process. Given One alternative solution by establishing islamic boarding school business institutions (such as institutions baitul maal wa tamwil (BMT) or boarding school cooperatives). This is reinforced by Zott and Massa (2011), Ritter and Lettl (2018) through this business model is able to answer fundamental questions in the business unit for the use of its six fundamental components, value proposition, customer, competence process, external position, economic model, and investor factor (such as who the customer is? What is the value of the customer? How does the business unit make money in this business unit?). So the business unit of islamic boarding school Sidogiri is in addition to being a source of income can also be a means of learning santri as well as the needs of santri. PP Sidogiri in Pasuruan, East Java is one of the most well established business schools and designs all its business institutions in "Sidogiri Sharia Business Network" consisting of Kopontren Sidogiri, BMT UGT (Teachers Duty), and BMT MMU (Maslahah Mursalah lil Ummah). According to Spieth, et.al (2011), there are four main drivers of the business unit: 1) responsible efficiency, 2) complementary impacts, 3) shared values, and 4) integration of new things. 
The renewal of this research illustrates the business model practiced by islamic boarding school Sidogiri as a whole and formulates the right business development strategy for the business unit of PP Sidogiri in order to maximize the role and social function of the islamic boarding school business unit. from the results of this study is expected to be used to optimize the potential business model of Islam especially business units PP Sidogiri and other microfinance in Indonesia in the future. The results of this research are different from some studies previously conducted by Abdelkafi and Täuscher, (2016); Schaltegger et al., (2016), focusing only on business models on social institutions without formulating development strategies.

Overall, it is a form of value transformation produced by a islamic boarding school business model that not only focuses on commercial values but also considers different institutional logics (Randles \& Laasch, 2017; Ocasio and Radoynovska, 2016). This change will certainly affect the business development strategy used in the islamic business model. Therefore, based on experience owned by islamic boarding school sidogiri in developing its business network is an interesting study material to be researched because it can determine the right strategy in the development of islamic boarding school business which is expected to be applied to other business models of islamic boarding school. This study will find the strategy, the impact of managing business model islamic boarding school in islamic boarding school Sidogiri, Pasuruan.

\section{Literature Review and Theoretical Framework}

The business model describes how firms utilize inputs to produce output, including creating added value for their production, the use of a combination of inputs (products, services, resources and infrastructure) (Afuah, 2004; Osterwalder, Pigneur and Tucci, 2005). The same thing suggested by the business model can also be defined as the architecture for products, services and information systems, including description of business actors and regulations, potential benefits for various actors in it and sources of income. In its development the business model is not a new thing. According to Zott, Amit, and Massa (2011) explained that the business model is a new analytical unit that emphasizes the holistic approach so how the business unit creates value is not just catching it considering the business unit has an important role in the conceptualization of the proposed business model.

The term of islamic boarding school is always related to the cottage, usually called boarding school (Pesantren - PP). According to Dhofier (1982: 18) that pesantren comes from the word santri. The prefix of devotion to the word pesantren means "the abode 
of the santri". While the santri comes from the Tamil language which means teacher of the Koran. Another notion of the term santri comes from the Indian language, namely shastri which refers to people who know the holy books of religious books, or books of science and knowledge (Nasir, 2005: 80-82). So the context of the understanding of islamic boarding school is similar to that in the neighborhood there is a residential complex for the residence of the students (students). Housing is usually a plot of rooms as dormitory. The basic elements that must be fulfilled by islamic boarding school are cottage, mosque, teaching of classical Islamic books, kiai as founder and leader, and of course santri as student of science claimant.

Characteristics of islamic boarding school according to Dhofier (1985: 18) can be seen from the general pattern of traditional Islamic education, rihlah tradition (traveling for knowledge), and the system of teaching. The other characters of the islamic boarding school are called great traditions, such as baroque and rewards. Another phenomenon of islamic boarding school that is unique is his soul, the spirit that underlies and pervades all activities undertaken by the entire academic community boarding. In the course of the development of the era with a number of contradictions or anomalies of values in society, islamic boarding school conduct resistance in the form of reaction or response and adaptation. One reason is the nature of boarding liquidity. The liquidity of islamic boarding school can be seen from the history and orientation of islamic boarding school which always change with the times. Due to the development of islamic boarding school orientation, islamic boarding school is currently divided into three types (see Table 1)

TABLE 1: Type of Islamic Boarding School (PP/Islamic boarding school) in Indonesia.

\begin{tabular}{|c|c|c|c|}
\hline $\begin{array}{l}\text { Type of Islamic } \\
\text { boarding school }\end{array}$ & Characteristic & Example & Total \\
\hline \multirow[t]{4}{*}{$\begin{array}{l}\text { Islamic boarding } \\
\text { school Salaf }\end{array}$} & $\begin{array}{l}\text { 1) Management and administration of } \\
\text { islamic boarding school is very simple } \\
\text { with islamic boarding school management } \\
\text { system centered on kiai rules; }\end{array}$ & $\begin{array}{l}\text { - PP. Hidayatul } \\
\text { Mubtadiien } \\
\text { Liroboyo Kediri, }\end{array}$ & $\begin{array}{l}\text { Most type of } \\
\text { islamic boarding } \\
\text { school in } \\
\text { Indonesia, } \\
\text { approxiately } \\
8.905 \text { (2017). }\end{array}$ \\
\hline & 2) Very attached to kiai figures; & $\begin{array}{l}\text { - PP. Al-Falah } \\
\text { ploso Kediri }\end{array}$ & \\
\hline & $\begin{array}{l}\text { 3) The pattern and education system is } \\
\text { conventional or based on the old tradition } \\
\text { with the teaching and learning process is } \\
\text { unidirectional (kiai lecturing and santri } \\
\text { listen), the teaching method is known as } \\
\text { sorogan and bandongan (wetonan) and } \\
\text { does not recognize the class level; }\end{array}$ & $\begin{array}{l}\text { - PP. } \\
\text { al-Anwar-Sarang } \\
\text { Rembang }\end{array}$ & \\
\hline & $\begin{array}{l}\text { 4) Santri building and dormitory is not } \\
\text { arranged neatly and generally integrates } \\
\text { with nature. }\end{array}$ & $\begin{array}{l}\text { - PP. Pacul } \\
\text { Gowang- } \\
\text { Jombang }\end{array}$ & \\
\hline
\end{tabular}




\begin{tabular}{|c|c|c|c|}
\hline $\begin{array}{l}\text { Type of Islamic } \\
\text { boarding school }\end{array}$ & Characteristic & Example & Total \\
\hline \multirow{4}{*}{$\begin{array}{l}\text { Islamic boarding } \\
\text { school Khalaf } \\
\text { (modern) }\end{array}$} & $\begin{array}{l}\text { 1) Have management and administration } \\
\text { with modern standards; }\end{array}$ & $\begin{array}{l}\text { - PP. Darussalam } \\
\text { Gontor Ponorogo }\end{array}$ & \\
\hline & 2) Unbound or central to kiai figures; & $\begin{array}{l}\text { - PP. } \\
\text { al-Zaitun-Solo }\end{array}$ & $\begin{array}{l}\text { In Indonesia, this } \\
\text { type of khalaf } \\
\text { islamic boarding } \\
\text { school is not } \\
\text { much, } \\
\text { approximately } \\
878 \text { islamic } \\
\text { boarding school } \\
\text { (2017) }\end{array}$ \\
\hline & $\begin{array}{l}\text { 3) Have a modern education system and } \\
\text { pattern with a blend of curriculum } \\
\text { between religion-based teaching subject } \\
\text { and general knowledge-based teaching; }\end{array}$ & $\begin{array}{l}\text { - Darunnajah dan } \\
\text { Darurrahman, } \\
\text { Jakarta }\end{array}$ & \\
\hline & $\begin{array}{l}\text { 4) Facilities and forms of boarding schools } \\
\text { are more established, regular, permanent, } \\
\text { and usually fence }\end{array}$ & $\begin{array}{l}\text { - PP. } \\
\text { Thawalib-Padang } \\
\text { Panjang, } \\
\text { Sumatera Barat }\end{array}$ & \\
\hline \multirow[t]{4}{*}{$\begin{array}{l}\text { Islamic boarding } \\
\text { school Terpadu }\end{array}$} & 1) semi-salaf type as well as semi-khalaf; & $\begin{array}{l}\text { - PP Tebuireng } \\
\text { Jombang }\end{array}$ & $\begin{array}{l}\text { In Indonesia this } \\
\text { type of islamic } \\
\text { boarding school is } \\
\text { about } 4.284 \\
\text { islamic boarding } \\
\text { school (2017) }\end{array}$ \\
\hline & 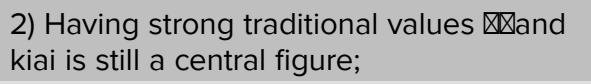 & & \\
\hline & $\begin{array}{l}\text { 3) norms and code of ethics of classical } \\
\text { islamic boarding school still become } \\
\text { standard of pattern of daily relations and } \\
\text { etiquette of santri in islamic boarding } \\
\text { school; }\end{array}$ & & \\
\hline & $\begin{array}{l}\text { 4) Adapting the modern education system } \\
\text { as a form of response or adjustment to } \\
\text { the development of nonpresantren } \\
\text { educational institutions }\end{array}$ & & \\
\hline ource & D05); Dhofier (2005: 41-42) & & \\
\hline
\end{tabular}

Every company needs a strategy to make it easier to achieve its goals. According to Jauch and Glueck (1991); Umar (2003) defines stragei as an integrated and integrated plan that links the company's strategy advantage with environmental challenges and is designed to ensure that the company's main objectives can be achieved through proper execution by the company. The formulation of strategies in it including developing the company's vision and mission, recognizing opportunities and threats, establishing the strengths and weaknesses of business units. For strategy implementation is a process of strategy implication with the intention of allocating resources and organizing according to strategy. Evaluation strategy is the final stage that the implementation will 
be evaluated to ensure that the adjusted strategy can achieve the company's goals. (david, 2004).

The process of developing this islamic boarding school business strategy indicates the flow in which the strategy of setting goals and formulating strategies (including strategy formulation, implementation and strategy evaluation). Of course, this development strategy involves all stakeholders both internally (santri, alumni, madrasah twig, and task teacher affairs) and externally (academics and practitioners).

The previous studi, Winter (2003) undertook research related to conceptual modeling of business networks and business strategy of financial services. The process of forming this model departs from the sophistication of the broader technical and organizational networks and allows the company to adapt faster innovations. The results indicate that the improvement of strategy modeling formulation becomes more specific so that the company re-design the business model. So it can adjust to the times.

Fauroni (2011) conducted a study related to the model of economic empowerment in PP Al-Ittifaq Rancabali, Bandung West Java. The factor of islamic boarding school selection toward economic empowerment is because islamic boarding school is a living social institution that has potency as a driving force in economic empowerment of people. The result of Al-Ittifaq islamic boarding school has succeeded in empowering the economy of society as expansion of islamic boarding school mission, through integrated empowerment model that is economic and business education and empowerment; gradual, and continuous and synergistic in the shade of islamic boarding school as well as strong network strength among elements.

Hendratmi and Widayanti (2017) examine the business model in Islamic perspective on BMT UGT Sidogiri East Java which is a business unit of Islamic boarding school Sidogiri, the method used in this research is a qualitative approach using case study method. The results show that there are three main buildings in the development of Islamic business model that consists of business foundation, business design, and business development.

\section{Methodology}

Type of research using qualitative descriptive method. The application of this qualitative method, consideration of the possibility of data obtained in the field of data in the form of facts that need an in-depth analysis of business model determination and business development strategy of islamic boarding school business unit Sidogiri. 
The focus of the research is the business model and strategy of islamic boarding school business development in an effort to run its role and social function. This type of research is a case study with the object of research used is PP. Sidogiri in Pasuruan, East Java which has a large business unit in the form of islamic boarding school business in the form of Kopontren Sidogiri, BMT UGT and BMT MMU.

The type of data used is secondary data obtained from the financial statements of Sidogiri business published from 2010-2017 (annual data) and other literature related to the management of islamic boarding school business model.

In this case study, the writer uses time series data and analysis using descriptive, where data obtained through observation (field reserch), interview, and documentation of library.

1. Technique of direct observation, the researcher directly make observation to the object under study;

2. Interview technique is done in depth deep interview. the informants of this study included the kyai (leader of each Islamic boarding school), managers, and students of Islamic boarding school PP Sidogiri. This election is because this informant is directly involved in business institutions on the Sidogiri Islamic boarding school.

3. Documentation and library techniques use published journals.

\section{Analysis and Result}

The establishment of this islamic boarding school is based on the founder's idea that the current education in Indonesia is faced with problems that have not been able to integrate the skills, independence, and personality of Islam. In fact, education today is more likely to educational capitalism. This is because the education system is not conducive yet, so the mandate of the 1945 Constitution has not been maximal. Therefore, the right solution is needed, to give birth to a Muslim generation who have Islam attitude and character, who comprehend science in a comprehensive and healthy physical (Rokhlinasari, 2004: 451). So islamic boarding school Sidogiri was established, located in Sidogiri, Kraton, Pasuruan. PP Sidogiri belongs to the integrated islamic boarding school category, incorporating salaf islamic boarding school and khalaf. Currently, the 266-year-old islamic boarding school (established in 1745) has about 5,000 students with exit (pass) -including about 500-700 each year.

Currently there are three business institutions Sidogiri which became business network PP Sidogiri. All three are BMT MMU, BMT UGT, and islamic boarding school 
Cooperative (Kopontren) Sidogiri. PP Sidogiri continues to add to their line of business through development in insurance and consulting services. However, both are new and not significant in the Sidogiri business network:

\section{BMT MMU (Maslahah Mursalah lil Ummah)}

BMT MMU incorporated Sharia Financial Services Cooperative (KJKS), so often also called KJKS Maslahah Mursalah Lil Ummah (MMU) Sidogiri or better known as Cooperative BMT MMU Sidogiri. MMU is one of sharia micro finance institutions that exist in islamic boarding school Sidogiri Pasuruan. Established since 1997 precisely at 12 Rabi'ul early 1418 Hijriah or 17 July 1997 with legal status 608 / BH / KWK.13 / IX / 1997 (4 September 1997). MMT MMU Cooperative Head Office is located at Jl. Raya Sidogiri No.09 Sidogiri Kraton Pasuruan.

The background of the establishment of BMT-MMU Pasuruan is started from the concerns of Madrasah Madrasah Miftahul Ulum islamic boarding school Sidogiri and Madrasah twigs or filial Madrasah Miftahul Ulum islamic boarding school Sidogiri for the behavior of people who tend to pay less attention to the rules of Islamic Shariah in the field of mu'amalat, whereas they are a Muslim society moreover they have started terlanda practices that lead to the usury economy that is strictly forbidden by religion. Asatidz and the madrasah officials conducted a study to find ideas that could answer the problems of the people. Finally found the idea to establish a joint business that leads to the establishment of sharia financial institutions that can raise and help the bottom of society whose economy is still in the micro (small) group.

\section{BMT UGT}

The cooperative of BMT-UGT (Baitul Maal wat Tamwil-Integrated Joint Venture) was established by several BMT-MMU boarders and people who were in one UGT-PPS (Teacher Training Division of Sidogiri Pondok Islamic boarding school) in which PJGT, Madrasah Leadership, Master, Alumni and PPS Participants spread in East Java. BMT-UGT started operations in Surabaya on 5 Rabiul Awal $1421 \mathrm{H}$ or 6 June $2000 \mathrm{M}$.

Thus, initially BMT UGT was established to facilitate business activities of teachers task (UGT), which is the practice of teaching duties for students who graduate madrasah tsanawiyah (junior high school) throughout Indonesia. With the BMT UGT, the activities of students who practice will be easier. In addition to teaching, they also participate in developing this BMT, especially in areas of Sidogiri alumni base. To avoid overlapping, BMT UGT and BMT MMU share the area. During 
this time, BMT MMU only operates in Pasuruan region, while BMT UGT operates in East Java area. BMT UGT will not develop BMTs in areas that are the base of MMU, and vice versa. Because it has grown rapidly, since 2010, each work area expanded. Currently, the work area of MMU is in East Java, and BMT UGT throughout Indonesia. Cooperative BMT-MMU and BMT-UGT is Baitul Mal Wat Tamwil Cooperative or Integrated Independent Business Center implementing Syari'ah Savings and Loans, its products use one of five contracts as follows: (1) Mudharobah / Qirod (Revenue Sharing) (4) Qord Al Hasan (Debt), and (5) Rahn (Pawn)

3. Islamic Boarding School coorperative (Kopontren) Sidogiri

Islamic boarding school Cooperative (called kopontren) Sidogiri is an institution that has great benefits for islamic boarding school, santri and the community. As a means of income islamic boarding school, as a means of learning santri in entrepreneurship and as a provider of daily needs of people with a fairly competitive price. The embryo of the founding of the cooperative can be traced from 1961, when it was KA. Sa'doellah Nawawie acting as Chairman and responsible Ponpes Sidogiri pioneered the establishment of cooperatives as a place to learn entrepreneurship of the santri in the form of food stalls and grocery stores.

Along with the time, until the caretaker of islamic boarding school Kyai Kholil Nawawie has started to form a management structure which means is to give full trust to the Board of Kopontren in making decisions related to Kopontren not have to wait for Kyai. Then in April 1997 filed a legal body of cooperative and on July 15, 1997, the deed of Legal Corporations of Sidogiri was issued. Along with the issuance of the legal entity, the business of Kopontren Sidogiri continues to increase until today. The establishment of this cooperative has a mission to become a productive Kopontren according to sharia principles so that it can be a strong and prospective fund for Sidogiri Boarding School. While the mission is: 1) Become the center of economy and business PP. Sidogiri; 2) Become a wholesale center; 3) Being a model pilot; 4) profit-oriented business.

As a boarding school that has stood and existed for almost three centuries, PP Sidogiri has a very large network. The network among others is (see Figure 1):

1. Santri (student) network

(a) Every year. Sidogiri that came out and entered +700 santri/student.

(b) Closed maids (living in boaring school) $+5,000$ santri/student. 
(c) Of the santri children, still have the potential of network that is the Wali Santri network of each santri/student.

2. branch madrasah network

(a) Madrasah Miftahul Ulum Sidogiri (Induk) has some branch madrasah, the following:

- MMU Ranting Ibtidaiyah for about \pm 68 Madrasah in Pasuruan.

- MMU Ranting Tsanawiyah for about \pm 16 Madrasah

3. UGT (Teacher task) network

(a) Every year the PP Sidogiri sends 500 - 700 santri/student graduated from MMU Tsanawiyah to be assigned to be a teacher in madrasah

(b) Madrasahs throughout Indonesia who requested the Teacher Duty (GT) by teaching for 1 year.

4. Alumni network (IASS/lkatan alumni Santri Sidogiri)

(a) Hundreds thousand of Alumni PP Sidogiri spread in Indonesia, Malaysia and Middle East

(b) The alumni have an organization of Santri Sidogiri Alumni Association (IASS) which in East Java there is Alumni Association Consortium Santri Sidogiri (PK-IASS) including in Malaysia and Middle East.

5. Participant of PP Sidogiri

(a) Academics

- Scientists

- Higher Education Institutions.

(b) Practitioners

- Other islamic boarding school around Pasuruan dan East Java.

- Other islamic boarding school around Indonesia.

- Syariah Banking.

- Cooperative dan IMFI

- Other economic institution.

The business model within the islamic boarding school business entity is the overall logic of the business applied in relation to its customers, its value chain, resources, operational management, to the design of revenue or profit and the sustainability of business 


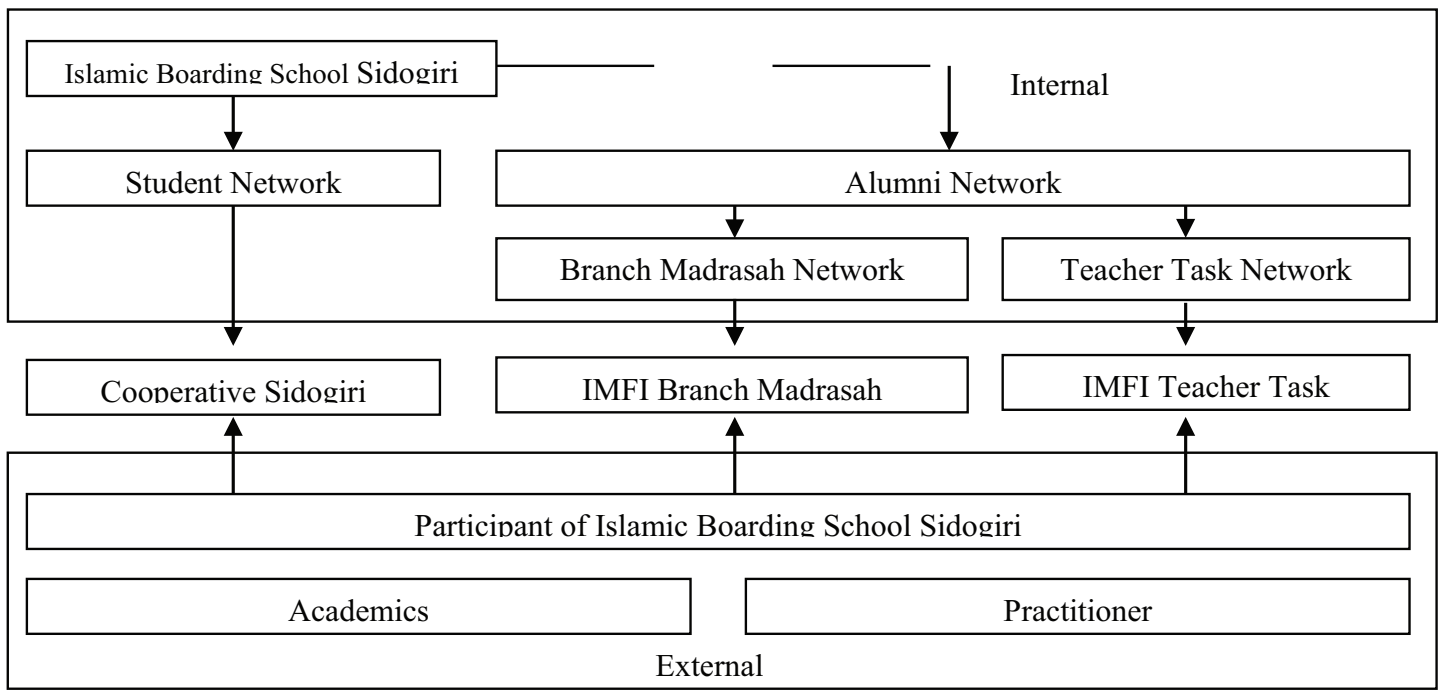

Figure 1: Business Network Islamic Boarding School Sidogiri.

entities. Because in essence this business model is able to explain how to overcome the lack of a system that previously existed, meaning the ideas of stakeholders involved can be crystallized into a solution to the problems that occur in focus. In theory, the business model includes elements, value proposition, market segment and revenue model, value chain, cost structure and profit potential, value network, and competitive strategy. To illustrate the business network model on Islamic boarding school Sidogiri can be shown with Figure 2 below:

\begin{tabular}{|c|c|}
\hline VALUE CHAIN & \multicolumn{2}{|c|}{ Ukhuwah } \\
\hline NETWORKING MODEL & Patterned communication \\
\hline \multirow{2}{*}{ OPERATING MODEL } & $\begin{array}{c}\text { Competitiveness } \\
\text { orientation }\end{array}$ \\
\cline { 2 - 3 } & $\begin{array}{c}\text { Orientation of virtue } \\
\text { assets as safekeeping }\end{array}$ \\
\hline VALUE PREPOSITION & Win-win Solution \\
\hline
\end{tabular}

Figure 2: Business Network Model in Islamic Boarding School Sidogiri.

In Figure 2 shows that there are three elements that form the basis of the business model run by PP Sidogiri namely value chain and networking model, operating model and value preposition. This is important considering the business model used is based on ukhuwah so that its fundamental basis is value chain and networking model supported by value preposition.

As a professionally managed institution, the business network of PP sidogiri must have a strategy system in running its business unit. The most fundamental thing is happening on environmental factors both internally and extensively that must be able 
TABLE 2: The Definition of Elements in Business Network Model PP Sidogiri.

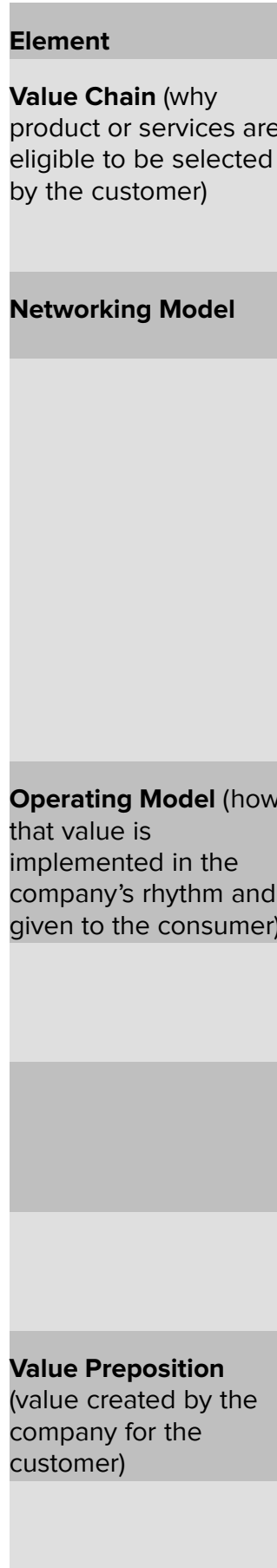



Customer and market orientation

Virtue Orientation

Quality, Quantity and Continuity

Win-win Solution

Common Prosperity

\section{Definis}

Ukhuwah means not only a brotherhood, but a close socio-economic and a significant influence on the achievement of society's progress. Ukhuwah expressed in attitudes and behaviors of community that character kohesiv, mutual trust, give and take, and mutual protection for progress together.

Trustful commitment of trust, mutual protection and advancement and commitment to compete in virtue

Principles and foundations of islamic boarding school in business development and empowerment of people. There are four underlying elements: (1) Divine $=$ economic and business development must depend entirely for God; (2) Person $=$ Successful economy and business must be supported by superior and competitive human resources (good work ethic); (3) Economy = all business activities must be well managed (professionally); (4) Kinship = all efforts are run on the principle of kinship (strong commitment and inner bond)

The process of innovation development in offering products that are produced (there is added value from the resulting product)

The balance between material and spiritual, market-oriented and avoids disappointing customers

Maintaining and promoting each other in strong partnership cooperation and high commitment in the development of islamic boarding school business

Prioritizing the overall business process by not excluding the quality, quantity and continuity factors of production

Able to create welfare improvement not only the parties directly involved (both internal and external) but also the surrounding community

It has a direct impact on improving social welfare or prosperity and social justice

to analyze the performance so as to be able to develop a business position that is run in order to provide a large multiplier effect for all parties involved, especially the surrounding community. The external point of view in Business Strategy Model PP Sidogiri is illustrated in Figure 3 below:

When looking at the Business Strategy Model run by PP Sidogiri in an external point of view will certainly discuss in terms of customers, pricing policies, services provided, the 


\begin{tabular}{|c|c|c|c|c|c|c|}
\hline & Orientation & Empowerment & Business & & & \\
\hline \multirow{4}{*}{ Customer } & $\begin{array}{c}\text { Basic } \\
\text { Orientation }\end{array}$ & Individual & SMSE's & $\begin{array}{l}\text { Unbankable } \\
\text { Customer }\end{array}$ & $\begin{array}{c}\text { Islamic } \\
\text { Consumer }\end{array}$ & \\
\hline & Potential & low constant & $\begin{array}{c}\text { low } \\
\text { increasing }\end{array}$ & $\begin{array}{l}\text { medium } \\
\text { constant }\end{array}$ & $\begin{array}{l}\text { medium } \\
\text { constant }\end{array}$ & High \\
\hline & Brand Design & traditional & convenience & community & discount & Inovative \\
\hline & Price Policy & $\begin{array}{l}\text { value or } \\
\text { volume }\end{array}$ & transaction & time & performance & \\
\hline \multirow{5}{*}{$\begin{array}{l}\text { Service } \\
\text { Offered }\end{array}$} & Sales Channels & Sales & Financing & Saving & invesment & \\
\hline & Success factors & convenience & time & $\begin{array}{l}\text { competence } \\
\& \text { quality }\end{array}$ & $\begin{array}{l}\text { Brand } \\
\text { Image }\end{array}$ & $\begin{array}{c}\text { value added / } \\
\text { cost } \\
\text { efficiency }\end{array}$ \\
\hline & Service & consulting & Sales & Information & $\begin{array}{c}\text { complaint } \\
\text { management }\end{array}$ & \\
\hline & Success factors & price / costs & risk & Flexibility & rentability & Image \\
\hline & Service type & $\begin{array}{c}\text { Product } \\
\text { oriented } \\
\text { (goods and } \\
\text { services) }\end{array}$ & Financing & Saving & Others & \\
\hline
\end{tabular}

Figure 3: External View of Business Strategy Model PP Sidogiri.

resulting output. In terms of customer segmentation is divided into individuals, MSMEs that require funds for business development, unbankable parties, and large potential from Muslim communities, or parties from the bottom to the bottom who require the existence of a business unit of PP Sidogiri. From the services offered there are four things: sales, storage, investment and financing, the success rate of service occurs when the service is satisfactory, the efficiency in the cost, the service is fast, the competence and the quality of the human resources is good and the brand image is also good of course this will affect the business performance network from PP Sidogiri. As for the internal perspective of Business Strategy Model PP Sidogiri described in Figure 4 below:

From an internal perspective Business Strategy Model run by PP sidogiri focuses more on organizational competence, organizational culture and value chain. In terms of value chain business strategy this model is influenced by stakeholders involved both santri/student, alumni, community, and sympathizers. As for organizational competence more directed to the ability of each HR, technology, capital, reputation and mentality involved in the Management oriented, output oriented and transformation oriented. In the organizational culture is more related to the openness and orientation of the implementation of business entities.

Broadly speaking, this chart can be used as a reference and example for the business network as an effort to develop the business model either theoretically or practically:

In this case, the business development process of PP Sidogiri (see Figure 5), consists of four stages: (1) The restructuring process, this process is the beginning of the business 


\begin{tabular}{|c|c|c|c|c|c|c|}
\hline & Orientation & Empowerment & Business & & & \\
\hline \multirow{2}{*}{$\begin{array}{l}\text { Value Chain } \\
\text { Properties }\end{array}$} & $\begin{array}{c}\text { Degree of } \\
\text { integration of } \\
\text { partners }\end{array}$ & Student & Alumni & Sympathizer & Community & \\
\hline & $\begin{array}{c}\text { Degree of } \\
\text { integration of } \\
\text { channels }\end{array}$ & Products & $\begin{array}{l}\text { Processes \& } \\
\text { systems }\end{array}$ & Finance & Marketing & \\
\hline \multirow{2}{*}{ Competences } & $\begin{array}{c}\text { Competence } \\
\text { sources }\end{array}$ & Employees & $\begin{array}{l}\text { culture \& } \\
\text { mentality }\end{array}$ & Technology & capital & reputation \\
\hline & $\begin{array}{c}\text { Competence } \\
\text { impacts }\end{array}$ & $\begin{array}{c}\text { management } \\
\text { oriented }\end{array}$ & $\begin{array}{c}\text { output } \\
\text { oriented }\end{array}$ & $\begin{array}{l}\text { transformation } \\
\text { oriented }\end{array}$ & & \\
\hline \multirow{3}{*}{ Organization } & $\begin{array}{l}\text { Management } \\
\text { policy }\end{array}$ & $\begin{array}{c}\text { high degree of } \\
\text { control }\end{array}$ & $\begin{array}{c}\text { general } \\
\text { frameworks }\end{array}$ & & & \\
\hline & $\begin{array}{l}\text { Processes and } \\
\text { structures }\end{array}$ & $\begin{array}{l}\text { formalized \& } \\
\text { standardized }\end{array}$ & $\begin{array}{c}\text { problem } \\
\text { oriented \& } \\
\text { subject } \\
\text { oriented }\end{array}$ & & & \\
\hline & Responsibilities & Centralized & Decentralized & task oriented & & \\
\hline \multirow[t]{2}{*}{ Culture } & Openness & $\begin{array}{c}\text { internal } \\
\text { orientation }\end{array}$ & $\begin{array}{c}\text { eksternal } \\
\text { orientation }\end{array}$ & & & \\
\hline & Orientation & community & individuality & & & \\
\hline
\end{tabular}

Figure 4: Internal View of Business Strategy Model PP Sidogiri.

\begin{tabular}{|c|c|c|c|}
\hline $\begin{array}{l}\text { Restructure } \\
\text { leadership and } \\
\text { management in PP } \\
\text { Sidogiri business } \\
\text { network }\end{array}$ & $\begin{array}{l}\text { Delegate } \\
\text { leadership } \\
\text { authority to } \\
\text { designated } \\
\text { human resources }\end{array}$ & $\begin{array}{l}\text { Pre-post production } \\
\text { activities in the } \\
\text { business network } \\
\text { (development model, } \\
\text { business strategy and } \\
\text { marketing) }\end{array}$ & $\begin{array}{l}\text { Calculate } \\
\text { contributions in the } \\
\text { implementation of } \\
\text { business network } \\
\text { (evaluation process) }\end{array}$ \\
\hline
\end{tabular}

Figure 5: Framework of Business Development PP Sidogiri.

network process as the development of islamic boarding school business model. The target of this process is the modernization in the management structure. Because the traditional role of central kyai in the leadership of boarding school, so that with the restructuring is expected kyai role will focus on the aspect of community service and devotion (social aspect), while the management and development of PP is held by the representatives of caregivers and board that has been appointed); (2) After restructuring in the business network, the delegation of authority in leadership to competent and committed human resources who have been appointed and obtained approval from kyai, so in this case the PP as an educational and social institution can run in tandem; (3) In this section more focus on the stages for pre and post development process. Surely this will be closely related to the business network owned by PP Sidogiri; (4) Conduct a thorough evaluation through the calculation of the contribution provided by the business network of PP Sidogiri. if there is a business field that does not contribute, it 
can be evaluated as a form of improvement so that it can continue to provide usefulness for the surrounding community.

\section{Conclution}

Business network model is a form of business development strategy islamic boarding school that can not be separated from the role and social function of PP Sidogiri. This economic exploitation certainly involves all components of the business network owned by a large PP Sidogiri, among others santri, madrasah twig, UGT, alumni and sympathizers who form a unified whole as a business network. The business network consists of three elements that form the basis of the business model run by PP Sidogiri, namely value chain and networking model, operating model and value preposition with ukhuwah as its fundamental foundation.

As a professionally managed institution, the business network of PP sidogiri must have a strategy system in running its business unit. The most fundamental thing is happening on environmental factors both internally and extensively that must be able to analyze the performance so as to be able to develop a business position that is run in order to provide a large multiplier effect for all parties involved, especially the surrounding community. business strategy model run by PP Sidogiri in external point of view of course will discuss from the aspect of customer, pricing policy, service given, the output it produces. While the internal business strategy Model run by PP Sidogiri focuses more on organizational competence, organizational culture and value chain.

In the process of developing business network PP Sidogiri requires all four stages to be traversed systematically and tersturktur, namely: Conducting restructuring of leadership and management in business network, delegating leadership authority to designated human resources, Pre-post production activities in business network (development model, business and marketing), and count contribution in the implementation of business network (evaluation process).

\section{References}

[1] Abdelkafi, N., Täuscher, K., 2016. Business models for sustainability: from a system dynamics perspective. Organ. Environ. 29, 74-96

[2] Arifin, A.Z., 2013. Charisma and rationalisation in a modernising Pesantren: changing values in traditional Islamic education in Java. 
[3] Afuah, A. 2004. Business models: A strategic management approach. New York: Irwin/McGraw-Hill.

[4] Dhofier, Zamakhsyari. 1983. Tradisi Pesantren Studi tentang Pandangan Hidup Kyai. Jakarta: LP3S.

[5] Fauroni, R Lukman. 2011.Model Pemberdayaan Ekonomi Ala Pesantren Al-Ittifaq Rancabali Kab. Bandung. Inferensi, Jurnal Penelitian Sosial Keagamaan, 5 (1): 1-17

[6] Glueck, W.F., Jauch, L.R. 1988. Business Policy and Strategy Management. Singapore: McGraw Hill.

[7] Hendratmi, Achsania \& Widayanti, Mega Ayu (2017). "Business Model in Islamic Perspective: Practising of Baitul Maal Wattamwil (BMT) UGT Sidogiri East Java Indonesia". Journal of Management and Marketing Review, 2 (1) 43 - 52

[8] Idrus, S. Ali Jadid Al. 2017. Model Strategi Kemitraan Pada Lembaga Pendidikan Islam (Studi Kasus di Man 2 Mataram). Palapa: Jurnal Studi Keis/aman Dan IImu Pendidikan 5 (2): 20-39

[9] Izfanna, D. and Hisyam, N.A., 2012. A comprehensive approach in developing akhlaq: A case study on the implementation of character education at Pondok Pesantren Darunnajah. Multicultural Education \& Technology Journal, 6(2), pp.77-86.

[10] Mardyanto, Eko. 2016. Manajemen Kewirausahaan Pondok Pesantren Berbasis Agrobisnis (Studi Kasus di PP Mukmin Mandiri dan PP Nurul Karomah). Jurnal Fikroh, 9 (2): 199-218

[11] Magretta, J. 2002. Why business models matter. Harvard Business Review, 80(5): 86-92.

[12] Muhtarom, 2005, Reproduksi Ulama di Era Global, Resistensi Tradisional Islam, Yogyakarta: Pustaka Relajar.

[13] Nasir, Ridwan. 2005. Mencari Tipologi Format Pendidikan Ideal Pondok Pesantren Ditengah Arus Perubahan, Yogyakarta. Pustaka Pelajar.

[14] Ocasio, W., Radoynovska, N., 2016. "Strategy and commitments to institutional logics: organizational heterogeneity in business models and governance". Strateg. Organ. 14, 287-309

[15] Osterwalder, A., Pigneur, Y., \& Tucci, C. L. 2005. "Clarifying Business Models: Origins, Present and Future of The Concept". Communications of the Association for Information Science (CAIS), 16: 1-25.

[16] Pratikto, Heri, Siswanto, Ely, \& Suparti. 2016. "Islamic- Based Student Cooperation Model An Effort To Increase The Interest In Entrepreneurship", IOSR Journal of Business and Management, 18 (1): 13-24 
[17] Rahardjo, Dawam. 1985. Pergaulan Dunia Pesantren Membangun Dari Bawah. Jakarta: P3M.

[18] Randles, S., \& Laasch, O., 2016. "Theorising the normative business model". Organ. Environ. 29, 53-73

[19] Ritter, T. and Lettl, C., 2018. The wider implications of business-model research. Long Range Planning, 51(1), pp.1-8.

[20] Rokhlinasari, Sri. 2014. Budaya Organisasi Pesantren dalam Pengembangan Wirausaha Santri di Pesantren Wirausaha Lan Taburo Kota Cirebon. Holistik, 15 (02): 443-60.

[21] Schaltegger, S., Hansen, E.G., Lüdeke-Freund, F., 2016. Business models for sustainability: origins, present research, and future avenues. Organ. Environ. 29, 3-10

[22] Spietha, Patrick, Schneidera, Sabrina, Claub, Thomas\& Eichenberg, Daniel (2018), "Value drivers of social businesses: A business model perspective" Long Range Planning, 51 (2):1-18

[23] Winter, Robert. 2003. "Conceptual Modeling of Business Networks and Business Strategies". 16th Bled eCommerce Conference eTransformation; 551-68

[24] Zott, Christoph, Amit, Raphael. 2003. "Business Models and Strategy of Entrepreneurial Firms", Mimeo, INSEAD.

[25] Zott, Christoph, Amit, Raphael, and Massa, Lorenzo. 2011. "The Business Model: Recent Developments and Future Research", Journal of Management, 37 (4): 101942. 